\title{
A study on the effect of interest rate on performance of stock exchange: A case study of Tehran Stock Exchange
}

\section{Saeid Aghasia ${ }^{a}$, Seyed Mahmoud Reza Hejazi ${ }^{b}$, Mohammad Malekmohammadi Faradonbeh ${ }^{\text {b* }}$ Akram Javanbakht ${ }^{b}$ and Fatemeh Malekmohammadi Faradonbeh ${ }^{b}$}

\begin{abstract}
${ }^{a}$ Assistant Professor, Department of Governmental Management, Dehaghan Branch, Islamic Azad University, Esfahan, Iran ${ }^{b}$ M.A student, Department of Public Administration, Islamic Azad University, Dehaghan Branch, Esfahan, Iran

C H R O N I C L E

\section{Article history:}

Received January 20, 2013

Received in revised format

28 March 2013

Accepted 16 April 2013

Available online

April 182013

Keywords:

Tehran Stock Exchange

Interest rate A B S T R A C T

Interest rate plays an important role on financial market in any different sectors from real state to auto industry. An increase on interest rates will increase cost of borrowing money from banks, which reduces profitability. The proposed study of this paper investigates the relationship between bank interest rates on performance of stock exchange over the period 2001-2010. The proposed study categorizes interest rates into five different categories including short-term interest rate, special short-term rate, one-year, two-year, three-year, four-year and five-year terms. The results of performing regression analysis have confirmed that there are some positive and meaningful relationship between interest rate in all groups and performance of stock exchange.
\end{abstract}

Stock market (c) 2013 Growing Science Ltd. All rights reserved.

\section{Introduction}

Interest rate plays an important role on fighting against inflation or heating up the economy. A lower rate of interest rate reduces the cost of borrowing for industry, which could increase motivation among business owners to expand their business. On the other hand, when inflation hikes, central banks of most countries increase prime interest rates to cool down their economies. There are literally various studies on the effects of different factors on Tehran Stock Exchange (TSE) (Ghalibaf Asle et al., 2012; Khodaei Valahzaghard \& Samadi, 2013; Tehrani et al., 2013; Hemmati \& Sayadi, 2013; Mohammadpour Zarandi \& Tabatabaei Mozdabadi, 2013). Raei and Bahrani Jahromi (2012) implemented decision makers' feedbacks based on multiple criteria decision making method to detect an appropriate portfolio. They first selected some important financial criteria and then using decision makers' opinions and by implementation of some fuzzy network analysis and they detected appropriate weights of the asset. The proposed model used two multiple criteria techniques namely TOPSIS and VIKOR and the model was examined for some real-world data from TSE. The results of the implementation of the proposed model were also examined against Markowitz traditional model.

Corresponding author. Tel: +989133809866

E-mail: sajadmalek68@yahoo.com (M. Malekmohammadi Faradonbeh)

(C) 2013 Growing Science Ltd. All rights reserved.

doi: 10.5267/j.msl.2013.04.015 
Houshmand Neghabi and Morshedian Rafiee (2012) studied the effects of different influential factors on capital structure of different sectors of industries listed on TSE. They used the financial information of 107 selected companies from 18 various industries listed on TSE over the period of 2004-2011 covering 40\% of total number of companies listed in this stock exchange. They used ordinary least square technique to examine the relationships. The results of the survey indicated that there was a positive relationship between tax rate and firm's growth rate, and capital structure. The result of the survey also indicated that there was a negative relationship between firm's profitability and capital structure. However, there was no evidence to believe that there had been any relationship between fixed assets and capital structure. They concluded that there was a negative relationship between firm's profitability and capital structure but the results of our survey did not indicate that there was any difference between the mean of profitability in various sectors.

Mohammadzadeh et al. (2012) presented an empirical study to find important issues as barriers for investment on TSE market. The study categorized the issues into two groups of real world and legal issues. Since there were different issues involved as major barriers, the study used analytical hierarchy process to rank them. The study extracted 18 important factors, which influenced investors' participation on TSE and using Borda method, prioritized them. The results of their survey indicated that in terms of real issues, Increase in quality of firms Financial Statement was number one priority followed by Increase stock exchange and agents' proficiency and electronic equipment, Unchangeable investment market rules and bounding organization managers to flow them and Strict supervision on agents' activities. In terms of legal issues, good supervision of provisions to force firms to reveal information correctly and restrict their secret bargaining was the most important factor followed by Using indirect investment guideline instead of direct investment, Increase in quality of firms’ Financial Statement and Investors’ training toward their rights.

\section{The proposed study}

The proposed study of this paper considers the effect of interest rate on performance of stock exchange. The main hypothesis of this survey is as follows,

Main hypothesis: There is a meaningful relationship between interest rate and stock exchange index.

The main hypothesis of this survey consists of the following eleven sub-hypotheses,

1. There is a meaningful relationship between interest rate and major index of Tehran Stock Exchange.

2. There is a meaningful relationship between interest rate and the primary index of Tehran Stock Exchange.

3. There is a meaningful relationship between interest rate and the secondary index of Tehran Stock Exchange.

4. There is a meaningful relationship between interest rate and cash return price index of Tehran Stock Exchange.

5. There is a meaningful relationship between interest rate and cash return index of Tehran Stock Exchange.

6. There is a meaningful relationship between interest rate and Pharmaceutical Industry index of Tehran Stock Exchange.

7. There is a meaningful relationship between interest rate and Auto Industry index of Tehran Stock Exchange.

8. There is a meaningful relationship between interest rate and Oil Industry index of Tehran Stock Exchange.

9. There is a meaningful relationship between interest rate and Chemical Industry index of Tehran Stock Exchange.

10. There is a meaningful relationship between interest rate and Cement Industry index of Tehran Stock Exchange. 
The proposed study of this paper investigates the relationship between bank interest rates on performance of stock exchange over the period 2001-2010. The proposed study categorizes interest rates into five different categories including short-term interest rate, special short-term rate, one-year, two-year, three-year, four-year and five-year terms. The study chooses the information of 100 firms from five industries including auto industry, chemical, oil and gas, cement and Pharmaceutical. Since we intend to use regression analysis, we need to confirm whether all data are normally distributed or not. Table 1 demonstrates the summary of performing Kolmogorov-Smirnov test.

\section{Table 1}

The summary of Kolmogorov-Smirnov normality test

\begin{tabular}{lccccccccc}
\hline & & Standard & \multicolumn{2}{c}{ Change } & \multicolumn{2}{c}{ Before conversion } & \multicolumn{3}{c}{ After conversion } \\
Index & Mean & deviation & coefficient & KS & P-Value & Result & KS & P-Value & Result \\
\hline Total & 10579.13 & 3531.48 & 0.333 & 5.17 & 0.00 & Not normal & 0.97 & 0.12 & Normal \\
Primary & 11250.55 & 4464.71 & 0.3968 & 7.31 & 0.00 & Not normal & 1.03 & 0.10 & Normal \\
Secondary & 14275.56 & 7548.34 & 0.528 & 11.18 & 0.00 & Not normal & 1.11 & 0.08 & Normal \\
Cash price & 41190.17 & 26394.77 & 0.058 & 11.12 & 0.00 & Not normal & 1.11 & 0.18 & Normal \\
Cash & 4575.73 & 886.05 & 0.193 & 5.96 & 0.00 & Not normal & 0.87 & 0.14 & Normal \\
Pharmaceutical & 575.52 & 223.72 & 0.389 & 9.09 & 0.00 & Not normal & 0.99 & 0.11 & Normal \\
Auto Industry & 3942.2 & 1578.02 & 0.400 & 2.83 & 0.00 & Not normal & 0.24 & 0.58 & Normal \\
Oil and Gas & 26655.95 & 3971.76 & 0.149 & 5.26 & 0.00 & Not normal & 0.79 & 0.22 & Normal \\
Chemical & 516.16 & 126.26 & 0.244 & 3.13 & 0.00 & Not normal & 0.39 & 0.48 & Normal \\
Cement & 219.2 & 61.76 & 0.281 & 6.38 & 0.00 & Not normal & 0.38 & 0.48 & Normal \\
\hline
\end{tabular}

As we can observe from the results of Table 1, none of the variable is normally distributed but when we perform a conversion all of them have been normally distributed based on Kolmogorov-Smirnov test when the level of significance is five percent. Therefore, we can use the following regression analysis to test all hypotheses of this survey.

$y=\beta_{0}+\beta_{1} x_{1}+\beta_{2} x_{2}+\beta_{3} x_{3}+\beta_{4} x_{4}+\beta_{5} x_{5}+\beta_{6} x_{6}+\beta_{7} x_{7}+\varepsilon$,

where $x_{i}, i=1, \cdots, 7$ represent short term interest, special short term interest, 1-year, 2-year, 3-year, 4year and 5-year interest rates, respectively. Next, we present details of our finding for testing all hypotheses of this survey.

\section{The results}

In this section, we apply stepwise regression analysis to test different hypotheses of this survey.

\subsection{The first hypothesis: Interest rate and Total index}

The first hypothesis of this survey is associated with the relationship between interest rate and Total index of Tehran Stock Exchange. The implementation of stepwise regression technique yields the following results

$$
\begin{array}{rrrrr}
y=86349.4 & -8808.67 & x_{1}+2250.124 x_{2}+11143.43 x_{3}-10776 x_{7}+\varepsilon, & \text { Adjusted R-Square }=0.494 \\
2215.83 & 288.31 & 81.89 & 262.32 & 262.35 \\
\text { t-value } 38.9 & -30.66 & 31.14 & 42.48 & -41.08
\end{array}
$$

As we can observe from the results of Eq. (2), three variables did not come to the final results of regression analysis and only four variables are statistically meaningful and based on the results we can confirm the first hypothesis of the survey.

\subsection{The second hypothesis: Interest rate and primary index}

The second hypothesis of this survey is associated with the relationship between interest rate and primary index of Tehran Stock Exchange. The implementation of stepwise regression technique yields the following results 


$$
\begin{aligned}
& y=110254.8-10187.9 x_{1}+2555.31 x_{2}+13562.88 x_{3}-13437 x_{7}+\varepsilon, \quad \text { Adjusted R-Square }=0.733 \\
& \begin{array}{llll}
1831.5 & 239.55 \quad 69.28 & 203.298 \quad 262.35
\end{array}
\end{aligned}
$$

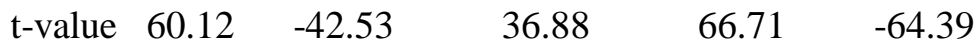

As we can observe from the results of Eq. (3), like the first hypothesis, three variables did not appear on the final results of regression analysis and only four variables are statistically meaningful and based on the results we can confirm the second hypothesis of the survey. The regression analysis can approximate approximately $73 \%$ of the changes on primary index.

\subsection{The third hypothesis: Interest rate and secondary index}

The third hypothesis of this survey is associated with the relationship between interest rate and secondary index of Tehran Stock Exchange. The implementation of stepwise regression technique yields the following results

$$
\begin{aligned}
& y=185252.8-15743.3 x_{1}+2575.17 x_{2}+25115.55 x_{3}-25868.0 x_{7}+\varepsilon \text {, Adjusted R-Square }=0.928 \\
& \begin{array}{lllll}
1603.34 & 209.72 & 60.66 & 177.9 & 182.37
\end{array} \\
& \begin{array}{lllll}
\mathrm{t} \text {-value } 115.5 & -75.07 & 86.96 & 141.18 & -141.84
\end{array}
\end{aligned}
$$

As we can observe from the results of Eq. (4), like the previous hypotheses, three variables did not appear on the final results of regression analysis and only four variables are statistically meaningful and based on the results we can confirm the third hypothesis of the survey. The regression analysis can approximate approximately 93\% of the changes on secondary index.

\subsection{The fourth hypothesis: Interest rate and cash index}

The fourth hypothesis of this survey is associated with the relationship between interest rate and cash return index of Tehran Stock Exchange. The implementation of stepwise regression technique yields the following results

$$
\begin{array}{ccc}
y=5694.74+415.94 x_{2}-320.61 x_{7}+\varepsilon, \text { Adjusted R-Square }=0.819 \\
207.962 & 5.03 & 13.27 \\
\text { t-value } 28.37 & 82.77 & -24.16
\end{array}
$$

As we can observe from the results of Eq. (5), five variables did not appear on the results of regression analysis. Therefore, only two variables are statistically meaningful and the results confirm the fourth hypothesis of the survey. The regression analysis can approximate approximately $82 \%$ of the changes on secondary index.

\subsection{The fifth hypothesis: Interest rate and cash price index}

The fifth hypothesis of this survey is associated with the relationship between interest rate and cash price index of Tehran Stock Exchange. The implementation of stepwise regression technique yields the following results

$$
\begin{array}{ccccc}
y=628866.4 & -63605.4 x_{1}+20588.3 x_{2}+86012.78 x_{3}-82124.2 x_{7}+\varepsilon, \text { Adjusted R-Square }=0.842 \\
7982.8 & 1048.17 & 305.12 & 857.93 & 890.92 \\
\text { t-value } 78.78 & -60.68 & 67.48 & 100.26 & -96.97
\end{array}
$$

As we can observe from the results of Eq. (6), three variables did not come to the final results of regression analysis and only four variables are statistically meaningful and based on the results we can confirm the fifth hypothesis of the survey. 


\subsection{The sixth hypothesis: Interest rate and Pharmaceutical index}

The sixth hypothesis of this survey is associated with the relationship between interest rate and Pharmaceutical index of Tehran Stock Exchange. The implementation of stepwise regression technique yields the following results

$$
\begin{array}{ccccc}
y=6422.21-625.36 x_{1}+197.14 x_{2}+826.38 x_{3}-833.21 x_{7}+\varepsilon, \text { Adjusted R-Square=0.839 } \\
92.71 & 10.58 & 3.49 & 10.48 & 11.49 \\
\text { t-value } 69.3 & -59.12 & 56.44 & 78.84 & -72.52
\end{array}
$$

As we can observe from the results of Eq. (7), three variables did not come to the final results of regression analysis and only four variables are statistically meaningful and based on the results we can confirm the sixth hypothesis of the survey.

\subsection{The seventh hypothesis: Interest rate and Auto industry index}

The seventh hypothesis of this survey is associated with the relationship between interest rate and auto industry index of Tehran Stock Exchange. The implementation of stepwise regression technique yields the following results

$$
\begin{aligned}
& y=24140.58-2744.76 x_{1}+522.98 x_{2}+2750.21 x_{3}-2430.50 x_{7}+\varepsilon \text {, Adjusted R-Square }=0.234 \\
& \begin{array}{lllll}
1217.84 & 157.91 & 45.01 & 144.17 & 144.19
\end{array} \\
& \begin{array}{lllll}
\mathrm{t} \text {-value } 19.82 & -17.38 & 11.62 & 19.08 & -16.86
\end{array}
\end{aligned}
$$

As we can observe from the results of Eq. (8), three variables did not come to the final results of regression analysis and only four variables are statistically meaningful and based on the results we can confirm the seventh hypothesis of the survey.

\subsection{The eighth hypothesis: Interest rate and Oil \& gas index}

The eighth hypothesis of this survey is associated with the relationship between interest rate and oil \& gas index of Tehran Stock Exchange. The implementation of stepwise regression technique yields the following results

$$
\begin{aligned}
& y=120601.4-5534.62 x_{1}+2063.36 x_{2}+9119.61 x_{3}-11412.4 x_{7}+\varepsilon, \text { Adjusted R-Square }=0.412 \\
& \begin{array}{lllll}
2671.78 & 348.07 & 99.04 & 315.62 & 315.72
\end{array} \\
& \text { t-value } 45.14 \quad-15.90 \quad 20.83 \quad 28.89 \quad-36.15
\end{aligned}
$$

As we can observe from the results of Eq. (9), three variables did not come to the final results of regression analysis and only four variables are statistically meaningful and based on the results we can confirm the eighth hypothesis of the survey.

\subsection{The ninth hypothesis: Interest rate and chemical index}

The ninth hypothesis of this survey is associated with the relationship between interest rate and chemical index of Tehran Stock Exchange. The implementation of stepwise regression technique yields the following results

$$
\begin{aligned}
& y=1724.95-226.39 x_{1}+24.65 x_{2}+152.40 x_{3}-103.25 x_{7}+\varepsilon \text {, Adjusted R-Square }=0.525 \\
& \begin{array}{lllll}
89.83 & 10.25 & 3.39 & 10.16 & 11.14
\end{array}
\end{aligned}
$$

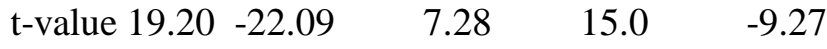


As we can observe from the results of Eq. (10), three variables did not come to the final results of regression analysis and only four variables are statistically meaningful and based on the results we can confirm the ninth hypothesis of the survey.

\subsection{The tenth hypothesis: Interest rate and cement industry index}

The tenth hypothesis of this survey is associated with the relationship between interest rate and cement industry index of Tehran Stock Exchange. The implementation of stepwise regression technique yields the following results

$$
\begin{array}{ccccc}
y=1065.26 & 39.28 x_{1} & -47.02 x_{2}+130.5 x_{3}+190.2 x_{7}+\varepsilon, \text { Adjusted R-Square }=0.820 \\
27.03 & 3.09 & 1.02 & 3.06 & 3.35 \\
\text { t-value }-39.41 & 12.74 & -46.16 & -42.7 & 56.77
\end{array}
$$

As we can observe from the results of Eq. (10), three variables did not come to the final results of regression analysis and only four variables are statistically meaningful and based on the results we can confirm the ninth hypothesis of the survey.

\section{Conclusion}

In this paper, we have presented an empirical investigation to study the effect of interest rate on different stock exchange as well as five important sectors on Tehran Stock Exchange. The study has collected the necessary information over the period of 2001-2010 and using stepwise regression model, different hypotheses have been examined. The results of the survey have indicated that the interest rate could influence all major indices as well as primary and secondary stock exchange.

\section{References}

Ghalibaf Asle, H., Khodaei Valahzaghard, M., \& Asadi Ahranjani, B. (2012). A survey on the relationship between stock liquidity with firm performance: A case study of Tehran Stock Exchange. Management Science Letters, 3(2), 635-640.

Hemmati, H., \& Sayadi, S.A. (2013). Earnings quality measures and excess returns: A case study of Tehran Stock Exchange. Management Science Letters, 3(4), 1133-1138.

Houshmand Neghabi, Z., \& Morshedian Rafiee, S. (2012). Investigating different influential factors on capital structure of different sectors of industries listed in Tehran Stock Exchange. Management Science Letters, 3(1), 73-80.

Khodaei Valahzaghard, M., \& Samadi, A. (2013). A study on relationship between tail risk on earning management in Iranian banking industry. Management Science Letters, 3(2), 705-714.

Mohammadzadeh, A., Hamidi, N., Abedi, S., \& Jabari, F. (2013). An application of multiple attribute group decision making in ranking investors' concerns: A case study of Tehran Stock Exchange. Management Science Letters, 3(2), 457-462.

Mohammadpour Zarandi, H., \& Tabatabaei Mozdabadi, S.M. (2013). A study on the effect of size and ratio of book value to market value on excessive return. Management Science Letters, 2(8), 3067-3072.

Raei, R., \& Bahrani Jahromi, M. (2012). Portfolio optimization using a hybrid of fuzzy ANP, VIKOR and TOPSIS. Management Science Letters, 2(7), 2473-2484.

Tehrani, R., Ahadi Serkani, S.Y., \& shokri, S. (2013). An investigation on the relationship between quarterly earnings adjustment and market value in selected firms listed on TSE Exchange. Management Science Letters, 3(3), 821-826. 